\title{
Regional Integration and Transnational Politics: Popular Sector Strategies in the NAFTA Era
}

\author{
Maria Lorena Cook ${ }^{1}$
}

\section{Introduction}

On 1 January 1994, Mexico's long-awaited entry in to the First World-symbolized by its alliance, through the NAFTA, with the largest economic power in the world - was quickly overshadowed by the appearance of what the New York Times called "the first Latin American revolutionary movement of the post-cold war age" (Golden 1994a). Just as the North American Free Trade Agreement took effect, a group of Indian rebels calling themselves the Zapatista National Liberation Army occupied San Cristobal de las Casas and several other communities in Mexico's southernmost state of Chiapas, declaring war on the Salinas government and labeling NAFTA a death sentence for indigenous peoples. Within days, journalists and observers proclaimed the end of the neoliberalism for which the Salinas administration had been applauded throughout the world, and the Mexican political landscape was turned upside down.

Much has happened since that New Year's Day when Mexicans awoke to find hooded rebel fighters on their television sets: the assassination of presidential candidate Luis Donaldo Colosio, a relatively peaceful and heavily monitored election that ended in victory for the Partido Revolucionario institutional (PRI), another political assassination (of PRI General Secretary Francisco Ruiz Massieu) that revealed the presence of dangerous factional divisions within the ruling party, and a peso devaluation in December 1994 that ushered in Mexico's worst economic crisis in recent memory. Given this succession of events, the Chiapas uprising appears as the first in a string of shocking developments in a country that had not seen this level of armed protest and political violence for decades. The political dynamics that the rebellion in Chiapas set into motion are still unfolding and it maybe some time before there is a final resolution to the conflict and before the full effect of the uprising can be grasped. What is clear at this point, however, is that what happened in Chiapas not only drew international attention to the exclusionary aspects of the neoliberal economic reforms implemented by the Salinas administration (and which NAFTA was to consolidate and extend), but it also catalyzed a national movement for broader political reform in anticipation of the August 1994 presidential elections and beyond (Eaton 1994: IA; Fox 1994a). ${ }^{2}$

Chiapas also represented the first example of how the domestic and transnational networks that emerged during the pre-NAFTA-vote period (1990-3) would react to a post-NAFTA-vote crisis in Mexico. In the days immediately following the takeover of four communities by the Zapatista army, the Mexican government was slow to respond, and then did so

\footnotetext{
${ }^{1}$ The author would like to thank Douglas Chalmers, Michael Jimenez, Monique Segarra, Celia Toro, and Deborah Yashar for their insightful comments. A preliminary version of this essay was presented at the Center for International Studies, Harvard University, 15 Feb. 1994, and at the International Congress of the Latin American Studies Association, Atlanta Georgia, 10-12 Mar. 1994, as well as at the Columbia University Workshop on Poverty and Inequality in Latin America, 3-5 Mar.

${ }^{2}$ For an overview of these electoral reform measures in the wake of the Chiapas uprising, see Cook et al. (1994).
} 
through indiscriminate bombing of Indian communities. In contrast, Mexican civil society reacted with tremendous maturity and speed, seizing the opportunity both to push for a political solution to the conflict and to drive home the urgent need for a true democratic political reform. As one analyst noted, Chiapas revealed once again the tremendous gap (desajuste) that existed between civil society and the political system in Mexico (Hernandez Navarro 1994). International and US-based organizations-in particular, human rights groups-also swung into action, as did members of the US Congress, both those who had voted for and against NAFTA. Whether or not events surrounding the Chiapas rebellion will be representative of reactions to future political crises in the NAFTA era, it seems clear that the political environment first generated by the NAFTA negotiation and debate period has created new interests, new resources, new allies, and new arenas for strategic action by both governmental and non-state actors.

Recent discussions of the impact of neo liberal economic reforms on popular sectors in Latin America have tended to emphasize their demobilizing effects on popular organizations and social movements, many of which showed startling vitality just a few years ago. In Mexico, many independent labor and popular organizations saw the North American Free Trade Agreement as the extension of a process of economic liberalization that had been taking place since the mid-1980s, one that had brought real wage decline, employment loss, and growing inequality. At the same time, however, the prospect of a free trade agreement with the United States and Canada breathed new life into a variety of Mexican non governmental organizations (NGOs) and popular organizations, as they mobilized against the agreement in collaboration with Canadian and US counterparts. The result was a novel and unexpected by-product of the NAFTA process: a network of North American labor, environmental, human rights, and other citizens' organizations using international alliances to pressure their governments to modify the agreement ${ }^{3}$

In a somewhat paradoxical development, transnational coalitions of popular- sector organizations had emerged in response to what many labor unions, human rights groups, women's and community organizations, and other grassroots and civic organizations widely viewed as an anti-popular and exclusionary process - the free trade negotiations.

This chapter argues that although economic integration between the United States and Mexico had been taking place for some time, it was the formal recognition of this process as represented by the discussions surrounding the North American Free Trade Agreement that facilitated transnational political action by non-state actors. Whereas the globalization of the economy and the prevalence of neoliberal economic policies may be considered by some to undermine popular sector organization and actions, formal recognition of regional economic integration in North America has produced a 'transnational political' arena that has expanded the resources available to non-governmental groups, increased their leverage in domestic political arenas, and broadened their strategic options.

This chapter will examine the dimensions of this transnational political arena. What are its characteristics? How is it likely to evolve overtime? How is this arena similar to or different from other 'internationalized' phenomena that a

\footnotetext{
${ }^{3}$ On the development of these transnational coalitions, see Thorup (1991).
} 
number of analysts have begun to observe and describe? How might different kinds of actors take advantage of this new environment? In particular, how does the existence of a transnational political arena affect popular organizations and social movements (including labor movements) whose activities have traditionally taken place within national borders? Will a Mexico more tightly connected to the US market offer increased opportunities for the mobilization of Mexican social movements, or will it strengthen the barriers against popular organization and activism?

\section{NAFTA and the Emergence of a Transnational Political Arena}

Mexican President Carlos Salinas de Gortari's proposal to President George Bush to extend a Free trade agreement to Mexico represented for many the culmination of the liberal economic policies Salinas, and De la Madrid before him, had been following. Those who opposed NAFTA did so partly on the grounds that it would lock in economic policies that had produced further inequality and weakened the poor. NAFTA, many argued, was actually a charter of rights for multinational corporations, and ignored the needs of the majority of the population of all three of the countries involved. NAFTA would hurt the majority of citizens by constraining democratic government, limiting a country's ability to implement social programs, infringing on national sovereignty, and by further removing key decisions from citizens, forcing them to respond to the initiatives of private corporations protected by the agreement.

At the same time, some who pointed to NAFTAs possible adverse effects on the majority of the population also acknowledged a positive development: the emergence of a growing number of cross-border contacts between labor, environmental human rights, women's, and other citizens' groups in the three countries (Grinspun and Cameron 1993). What was emerging, and what was further needed, in response to the globalization of the economy was the globalization of social movements, the transnationalization of a political and social response to corporations, capital, and goods that moved freely across international borders (Brecher and Costello 1991a, 1991b). Whereas the globalization of the economy and regional economic integration have generally been viewed as harmful to popular organizations and national labor movements, some of the political changes that have accompanied these regional and global tendencies may point to the generation of a new, transnational political arena that could, in turn, broaden the range of strategies that national social movements may adopt.

The NAFTA debate acted as a catalyst to the formation of cross-border alliances. Since 1990, there has been an explosion of contacts between Canadian, Mexican, and US non-governmental groups. These have taken a variety of forms: site visits, educational tours and workshops, meetings attended by representatives of organizations from the three countries, regular communication and exchange of information (aided by faxes and access to computer networks), joint political strategizing around NAFTA, solidarity actions with specific struggles, pressuring of government officials and politicians to concern themselves with events in the other country, and so forth. Cross-border collaboration has taken place at both the grassroots level of people-to-people contacts and among organization leaders. ${ }^{4}$ This development of

\footnotetext{
${ }^{4}$ For a discussion of some of these cross-border efforts, see Brooks (1992), Eisenstadt (1.993), Hernandez Navarro (1993), Thorup (1991, 1993), and Browne et al. (1994).
} 
direct, people-to people networking in the three countries has been called citizen diplomacy and represents a novel dimension in US-Mexican relations. Some have argued that this citizen diplomacy can, therefore, act as an important, bottom-up check on traditional diplomatic relations and government-to-government exchanges (Thorup 1991, 1993).

This cross-border coalition formation took place in a unique historical context, one in which Mexico's economic and political future had come to depend-as never before-on a decision to be made in the US Congress. At the same time, NAFTAs passage was by no means a foregone conclusion, this meant that the political process in the United States was particularly porous on this issue. Congress was not only bombarded by the lobbying efforts of the Mexican government (producing the most expensive single-issue lobbying campaign by any foreign government thus far), but also by domestic constituencies, especially labor and environmental groups, and by the congressional testimony of Mexican citizens: representatives of popular organizations, Mexican NGOs, intellectuals, and even individuals who felt wronged by the actions of US companies in Mexico. ${ }^{5}$ Whereas before Mexican NGOs' international activities consisted, in the best of cases, of contacts with foundations or other social movements, now they were lobbying at the centers of political decision making, especially the U.S. Congress', where, increasingly, issues relating to Mexico were being decided (Hernandez Navarro 1993:10). Government officials and legislators have also crossed borders in recent years. US politicians flocked to Mexico, especially the border, to learn more about the concerns of their constituents, both those who favored and opposed the agreement, Mexican government officials have been especially active in the US political arena. Not only did they spend millions on lobbying and influential consultants in Washington, DC, but they targeted the opinion pages of major US newspapers and traveled throughout the country to campaign for NAFTA (Dresser 1993). The Mexican government especially tried to win over Hispanics in the USA in the hopes that they could act as a strong 'pro-Mexico' lobby in Washington.

The political opposition in Mexico also campaigned in the USA among Mexican immigrants, and declared its plans to lobby the US Congress and President Clinton on electoral and human rights issues (Hughes 1993a: 12). Competition between the Salinas administration and the opposition headed by Cuauhtemoc Cardenas for the hearts and minds of Mexican citizens residing in the USA even prompted the Mexican government to respond with an international version of Solidaridad, the government's public works program targeted at the poor (Hughes 1993H 13). However, it was in the political process and debate surrounding NAFTA that the interpenetration of the domestic politics of the United States and Mexico emerged most dearly. Thai domestic politics were 'internationalized' by the NAFTA debate became especially visible within Mexico. Their country long ruled by strong nationalist sentiments and mistrust for its northern neighbor, Mexico's political leaders have typically bristled at any criticism coming from the United States and felt little compunction to address its concerns. Because of its proximity to the United States and the history of US-Mexican relations, Mexico has dung more steadfastly to notions of national sovereignty than most other Latin American nations. These strong nationalist tendencies made themselves felt in the economic arena as well as in politics, even though Mexico's economy

\footnotetext{
${ }^{5}$ In one case, a woman fired from her job at a General Electric maquila due to prior union organizing activities was brought to the USA to testify before the US Senate. The United Electrical Workers, Teamsters, and Jobs with Justice were instrumental in bringing her to the United States.
} 
has always been strongly dependent on the United States. However, the gradual opening of Mexico's economy in the mid1980s and President Salinas's strong support of NAFTA have made it more difficult to sustain the nationalist discourse within Mexico and with other countries. Moreover, economic liberalization and restructuring in Mexico threaten to dismantle the regime's traditional domestic support coalition, affecting organized labor in particular, which constituted the strongest pillar of support during moments of nationalist or statist retrenchment vis-à-vis the United States or even the Mexican private sector.

The NAFTA political process made the Mexican government uncharacteristically responsive to outside criticism of its domestic policies and helped to shape the reform process within Mexico. US concerns with Mexico's environmental problems and lax enforcement: of its laws led President Salinas to revise environmental legislation and take a series of strongly visible measures aimed at assuaging these concerns. Complaints about corruption, drug trafficking, and human rights violation - issues that had led to tensions in US-Mexican relations in the past-led President Salinas to step up drug interdiction efforts, clean up the judicial police force, and appoint a former human rights advocate to the position of Attorney General. On political issues the Mexican government has been more tentative. Nonetheless, charges of authoritarianism from outside as well as pressure from domestic political opponents persuaded the regime to recognize opposition electoral victories in some states and to propose a series of electoral reforms, a process that received even greater impetus after Chiapas.

Mexico's authoritarian political system has traditionally limited the ability of domestic political opponents to influence the political process via elections or other domestic institutional means. In recent years, however, Mexican political reform was increasingly spurred and shaped by what happened in the USA. In extreme cases, a critical article in the Wall Street Journal or the New York Times could lead to a speedier change in government policy than years of domestic political pressure. It is little wonder, then, that some Mexican intellectuals, labor groups, human rights organizations, and opposition parties used the US political arena to press for change in their own country. The Mexican left, in particular, has overcome historic mistrust in order to build alliances with US and Canadian groups. Meanwhile, the NAFTA debate increased the contact points between international actors and the domestic political process in both the United States and Mexico, and it expanded the possible arenas available to non-governmental actors for strategic action on a range of issues, not all of them pertaining strictly to NAFTA.

With the initiation of government talks over NAFTA, then, several new developments emerged that have helped to define what may be termed a new transnational political arena in the North American region: (1) nan-state actors began to search across borders for common interests in trying to influence the NAFTA negotiations process; (2) international actors (governmental and non-governmental alike) began to scrutinize Mexican domestic politics more intensely; (3) the Mexican government became more sensitive and more responsive to external criticism as it waited for the fate of NAFTA to be decided in the US Congress; (4) some Mexican non-state actors obtained increased bargaining leverage within Mexico because of their relationship with international allies, and increased attention internationally because of their critical position within Mexico. 
The novelty of these developments becomes evident when one looks at the history of US-Mexican relations, which has largely involved government-to-government relations at the level of policy, frequently over problems shared due to geographical proximity-especially drug trafficking, immigration, pollution, and trade. While the social, cultural, and economic integration of the southwestern United States and northern and central Mexico has been a fact for some time, and Mexican political movements have at times spilled over into areas of the United States, the breadth of grassroots involvement and the intensity of Mexican government and non-governmental efforts to influence and organize public opinion in the USA are unprecedented. As Denise Dresser noted, 'For the first time in its post-revolutionary history, Mexico launched a new policy towards the United States in the United States' (Dresser 1993: 94). The novelty of these developments and of the political environment they have generated challenges us to rethink the ways in which sovereignty, domestic politics, and popular sector strategies take shape in North America.

\section{The Internationalization of National Politics: Rethinking the Strategic Arena}

Recently, many analysts seem to be wrestling with new ways to describe and conceptualize what appear to be new global developments. These have been variously described as the interpenetration of international and domestic spheres, 'internationalized politics', or the 'new transnationalism'. ${ }^{6}$ Douglas Chalmers, for instance, has argued that internationalizing trends in the areas of the economy, communications, culture, and politics have introduced international actors at all points within the domestic political process, thereby 'internationalizing the politics of states' (Chalmers 1991: 6 -7). According to Chalmers, these internationalizing trends are changing the way we think about the basic units in the international system, aspects of the 'nation', the significance of territorial borders, and the utility of notions of foreign policy that presume a model of separate, territorial nation states, Sikkink (1993) has argued that 'transnational nonstate actors' such as nongovernmental organizations and transnational social movements are increasingly influencing state policies, particularly In certain issue-areas, just as foreign governments, international organizations, and transnational corporations have traditionally done. For his part, Rosenau has described a 'multi-centric system of diverse types of actors [that have] emerged to rival the anarchic world of nation states' (Rosenau 1993:20). How does the political arena generated by NAFTA relate to some of these internationalized processes that other authors have sought to analyze?

Sikkink talks about the emergence of 'principled issue-networks': networks of international and domestic nongovernmental organizations, global and regional intergovernmental organizations, and private foundations organized around shared values or principled ideas -in this case, human rights. These international human rights networks challenge traditional concepts of national sovereignty by seeking to redefine what is within the domestic jurisdiction of states in attempting, to alter state practices (Sikkink 1993:413). The targets of these international issue-networks in the area of human rights depend in part on the political context, in part on the extent and severity of the violations. In Argentina, gross human rights violations under the military government in the mid-1970s attracted the network's attention, as did

\footnotetext{
${ }^{6}$ Benedict Anderson has referred to the efforts of foreign resided in the centers of global economic and political power to influence politics in their countries of origin as 'E-mail nationalism' (The Origins of E-Mail Nationalism and its Consequences', presentation to the International Studies in Planning Spring Seminar Series, Cornell University, 25 Feb. 1994).
} 
rights violations in Central America during the 1980s. In Mexico, Sikkink points out the human rights network did not become active, despite the existence of gross rights violations in earlier periods (such as the 1968 massacre of students), until after Central America had faded from the screen, more domestic human rights groups had emerged in Mexico, and the NAFTA debate had begun to focus attention on Mexico (Sikkink 1993: 478-30).

While international issue-networks have become part of the new NAFTA environment, it seems clear that they did not create it. The international human rights network, for example, predates the new political arena created by the NAFTA debate, and to some degree turned its attention to Mexico because of this new political environment. It may also be that the NAFTA debate process has generated new networks organized around other kinds of issues, such as the environment and labor rights. In any case, while the presence of these networks is certainly part of what the transnational political arena is about, they are different phenomena. For example, geography is relatively unimportant for the networks that Sikkink describes. The human rights network might turn its attention equally to Pakistan, Argentina, or El Salvador; indeed, proof that location is relatively unimportant is that the focus turned toward Mexico, the United States' immediate neighbor, only recently. In contrast, geography-the idea of a 'region'-appears to be central for the transnational political arena this study attempts to characterize.

One author who has advanced the discussion on how to talk theoretically about a regional arena is James Rosenau (1993), in his discussion of what he calls 'The California-Mexico Connection'. The California-Mexico Connect ion refers to a region marked by the overlap and flow of people, culture, and 'issues' that affect both California and Mexico. While NAFTA is not central to the Connection's existence (the Connection predates NAFTA), NAFTA is likely to expand and strengthen the ties that bind these geographic areas, and may bring them into greater 'coherence'. What distinguishes this region is the geographical contiguity of the two national areas and the social, cultural, and economic linkages that derive from this contiguity. From this perspective, it is unlikely that we would ever speak of a New York-Mexico Connection, even with NAFTA, For the transnational arena produced by NAFTA, geography is important, but not in the same way that it is important in the case of the California-Mexico Connection. NAFTA redraws the geographical boundary around three nation-states, not simply between regions within countries. This regional area then becomes important lo the concept of a transnational political arena because of the formal recognition of economic ties, the meanings people give to these ties, and the possibilities for political action and alliances that they engender. Cultural similarities exist within this arena, but are not necessary for its existence. ${ }^{7}$ Finally, the California-Mexico Connection is defined by the presence of unorganized phenomena (people, goods, problems) in the region, rather than by the actions of organized groups and the adaptation of their political strategies to a new terrain. The transnational space produced by NAFTA therefore differs from that of the California-Mexico Connection.

The development of regional trading blocs in the world has also begun to spur new ways of thinking about the

\footnotetext{
${ }^{7}$ Similarly, one important component of the transnational arena, that which relates to immigration and migratory circuits, is a large part of the California-Mexico Connection but also extends beyond California, the concept of 'transnational communities' used to talk about Mexican immigrants in the United States refers to Mexican village identities and networks spanning both Michoacán and Redwood City, Oaxaca and Fresno, Puebla and New York City (see R. Smith 1992).
} 
politics that occurs within these regional blocs. Even though the European case involved a higher degree of institutionalization at the supranational level and a more explicit recognition of the need for harmonization, regional integration in both Europe and North America has involved a similar set of pressures. ${ }^{8}$ European economic integration, with its accompanying political-institutional changes at the supranational level, has raised the question of whether domestic institutions and practices should or do converge to meet international demands during integration. Suzanne Merger, for example, observed how domestic structures and practices become the object of pressure and the subject of international negotiation during the process of integration in Europe. ${ }^{9}$ This negotiation was being driven by market forces, but also by social and political demands for 'fair trade', which calls for 'leveling the playing field' among trading partners. Robert A. Pastor (1992) argues something similar in the case of NAFTA: what had been termed only an agreement about trade and investment in fact drew attention to a range of non-trade issues, such as human rights, the environment, labor, and politics. In North America, the existence and pressure of non-governmental groups opposed to NAFTA was an important factor in extending the debate. The question of labor and environmental standards, for example, became part of the agenda due to pressure from environmental organizations and the labor movement in the United States. Much of the opposition to NAFTA and pressure to expand the debate also stemmed from the fact that such great disparities existed between the United States and Mexico in terms of levels of economic development and the character of their political institutions. Thus, the importance assigned to non-trade issues depended ultimately on the meanings that non-govern mental groups assigned to the process of regional integration and what they believed its implications would be. Indeed, asymmetry has been an important factor in expanding the terms of the debate in the NAFTA case and in generating a transnational political arena. Mexico was in general, the weaker partner in the NAFTA negotiations; its dependence on US Congressional approval drove Mexican government and party officials to lobby the US government, Congress, and public opinion and helped to shape the domestic reform process within Mexico. Different levels of economic development and different political systems sparked the concerns of the US labor movement, environmental groups, and other citizens' organizations, which saw NAFTA as lowering standards and eliminating jobs in the USA. The lack of democratic debate in Mexico also influenced the creation of a transnational arena. Unable to express dissent at home, Mexican organizations and individuals brought their dissent to the US political arena, where criticism of Mexican government practices could generate greater results. ${ }^{10}$

What changed with the NAFTA debate was not so much the degree of institutional development nor even of economic integration, but the political context - in particular, the strategies that became possible and the resources that became available because of it. What changed were the meanings people ascribed to developments in each country and their willingness to engage with counterparts and allies across the border. The political environment therefore changed without (or prior to) significant institutional change. What was further distinctive about the arena generated by NAFTA and about the notion of transnational politics was that they acknowledged the existence of new arenas and resources for

\footnotetext{
${ }^{8}$ On the creation of new institutions in Europe, see the essays in Sbragia (1992).

${ }^{9}$ Presentation by Suzanne Berger to workshop on 'The Political Economy of the New Europe', Cornell University, Nov. 1992.

${ }^{10}$ See Aguilar Zinser (1993) for a discussion of the political restrictions on a NAFTA debate within Mexico.
} 
strategic action by organizations, groups, and movements that had traditionally beers bound by national borders. While one has to be careful not to underestimate the extent to which national factors continue to shape and, in many cases, determine the actions of these groups, it is important to recognize the ways in which the presence of a transnational area can shape domestic organizations' strategies.

One of the reasons why the international relations literature has proven inadequate for understanding some of the internationalizing developments described above is because these developments involve significant participation by nonstate, grassroots actors. The environment and actions of these actors have been more adequately dealt with by the rich theoretical literature on social movements. Nonetheless, this literature has tended to treat social movements as nationally bounded (Sikkink 1993; McAdam and Rucht 1993). As with other sub-fields and disciplines, the social movements literature also demands reconceptualization to take into account transnational developments; in this case, it requires rethinking the political environ merits of movements. Within the social movements literature, one approach has focused on how changes in movement environments - the existence or absence of 'political opportunities'-facilitate or impede movements' abilities to mobilize and to act. The determinants of a particular 'structure of political opportunities' were most often found to be national, political factors. ${ }^{11}$ The presence or absence of these factors could help to understand the timing of movement mobilization. For example, important variables in a political opportunity structure were whether institutional access existed; whether political (usually electoral) alignments were in disarray; whether there were conflicts within the political elite; and whether there were influential allies either from within or outside of the system (Tarrow 1991: 15).The relevant characteristics in this approach were typically associated with a type of polity (usually advanced industrial democracies) rather than a country's position in a regional or global economic system. Similarly the concept of a 'social movement sector' (the existence of a number of movements occurring more or less simultaneously and the relations among them) visualized such sectors as existing within national boundaries. In spite of the fact that this part of the social movement literature largely confined itself to discussions of national social movements; the concepts of this literature may be usefully applied to understand the contours of the transnational political arena and how movements may act within this arena. We may superimpose a set of transnational variables onto the national determinants of political opportunity structure, or simply extend these concepts to include their transnational, as well as domestic, dimension. In this way, the concept of social-movement sector may include not only the traditional, national array of social movements and domestic NGOs but also their counterparts in other countries. Influential allies may refer not only to domestic allies within or outside of the system but also to allies in neighboring states (whether from government, Congress, the labor movement, domestic NGOs, or other social movements) and to private foundations and international agencies (such as those involved in the human rights issue-network that Sikkink describes). ${ }^{12}$ Electoral alignments and political developments in the neighboring country or in the region may become just as important to a network

\footnotetext{
${ }^{11}$ Among authors writing from within this 'political process' perspective are Jenkins and Perrow (1977); McAdam f J9fl2); Kitschelt (1986); Brockett (1991); and Tarrow (1988, 199L 1994).

${ }^{12}$ On the importance of international allies for the human rights movement in Argentina, for example, also see Brysk (1993).
} 
of movements and organizations as political conditions in their own country. And institutional access may be sought elsewhere, and may be used to pressure for increased access at home. In the language of social movement theory, the NAFTA process has created a new structure of political opportunities, one that has generated a change in expectations and an expansion of the possible strategies and resources that various actors may adopt.

A transnational political arena is, consequently, one in which non-governmental and governmental actors utilize the political process and media networks of another country, and/or attempt to form contacts and alliances with nongovernmental actors of another country, in an effort to influence public opinion in that country and/or in an effort to affect the political process at home. To distinguish this arena from isolated, individual cases of cross-national activism, for such an arena to exist there must be a generalized awareness of the interrelatedness of the issues that emerge in each country, and a perception that formerly domestic issues carry repercussions for the citizens of another country, and therefore are subject to pressure by, and negotiation with, foreign actors. While these perceptions are difficult to measure, they can be observed in such statements as those by the Mexican deputy foreign minister who explained that the Mexican governments more partisan involvement in US politics on account of California ballot Proposition 187 was 'part of the new reality of [the US-Mexican] relationship' in which greater integration was changing the political rules observed by the two countries (Golden 1994b). The comments of Baldemar Velasquez, president of the Farm Labor Organizing Committee, which has a dose working relationship with its counterpart in Mexico, are also telling: 'Today, we have to look at ourselves as citizens in a collective economy as opposed to citizens of a particular nation' (Bryce 1993). A transnational political arena by definition challenges traditional notions of national sovereignty. While regional proximity may not be necessary for the existence of a transnational political arena, geographical contiguity may facilitate the breadth and frequency of cross-border exchanges. What further distinguishes a transnational political arena from some other kind of region with shared problems and a social and cultural overlap is that a transnational political arena is primarily about a political process: how the actors involved perceive and pursue power resources in order to gam bargaining leverage and to influence political decisions. Although cultural and social similarities and supranational institutions may exist in this arena, they are not essential for its existence. Moreover, it is an arena in which international issue-networks may operate, but these networks exist independently of a transnational political arena. Finally, although strong economic lies between Mexico and the United States had existed for some time, it was the formal recognition of these ties rather than the fact of their existence which helped to change actors' perceptions and strategies.

In the North American case, a transnational political arena was created when talks began on the North American Free Trade Agreement. What generated this arena was the effort to expand the agenda during the negotiations to include nontrade issues. The belief on the part of some actors that domestic non-trade issues then became subject to international negotiation helped to generate a political process and a set of strategies aimed at influencing this negotiation.

Asymmetry between the United States and Mexico was key in helping to forge this transnational political arena. The Canada-USA Free Trade Agreement of 1989 did not generate a similar process. The incorporation of Mexico, with its much smaller and less developed economy, its authoritarian political system, its weaker environmental protections, its lax enforcement of legislation, and its much poorer population immediately provoked the opposition of domestic interest 
groups in the United States, many of whom wanted to discuss the 'harmonization' of policies and standards and therefore expanded the terms of the debate. The differences in the ways that public policies are decided in each country also helped to forge a transnational arena. While in Mexico there was never any question that NAFTA would be ratified by the Mexican Senate, in the United States the executive could not ensure the outcome of the vote $\mathrm{m}$ the US Congress. This made the US Congress the site where NAFTA-and Mexico's economic and political future-would be decided. It also meant that congressional representatives were subject to political pressure by interest groups and constituencies, including Mexican governmental and non-governmental actors. The lack of a democratic debate within Mexico pushed Mexican citizens' groups into the US political arena as well. In addition, the more traditional power asymmetry in the relationship between the US and Mexico has meant that the 'domestic' policies that become subject to negotiation tend to be Mexican ones (or Canadian ones) rather than those in the United States. ${ }^{13}$

The new transnational politics arena created by the NAFTA process is therefore one In which (a) contacts and alliances have emerged among citizens' groups in the three countries on a range of issues; (b) new resources have become available to the Mexican groups, including the networks and resources of their international allies, and the possibility of funding from international sources; (c) the US Congress and the LS public have developed a heightened awareness of Mexican issues; (d) the number of Mexican non-governmental organizations has expanded and they have come to play a larger role both within Mexican society and in the international arena (especially in the case of human rights, environmental, and prodemocracy groups\}; (e) some groups (such as the labor movement) have adopted new strategies in their own struggles that incorporate a transnational element.

\section{The Transnational Arena and Labor Strategies}

This section will focus on some of the actions and strategies that have developed among US, Canadian, and Mexican labor organizations. Cross-border contacts and transnational strategies have taken place among an array of groups, as was mentioned above. Nonetheless, transnational strategies among labor unions have been among the most difficult and, in some ways, among the most important. Cooperation between US and Mexican labor organizations has been difficult because of a history of mistrust, misunderstanding, and ignorance, but also because for many in the labor movement, NAFTA involved a zero-sum game in which US job losses were viewed as Mexico's job gains (Browne el al. 1994, ch. 3). At the same time, the principal labor organizations in Mexico, such as the Confederation of Mexican Workers (OTM), refused to oppose the Salinas government on the NAFTA issue, making it difficult for US and Mexican unions to find common ground. The relatively limited political autonomy of most Mexican trade unions was another important factor

\footnotetext{
${ }^{13}$ Although the institutions established by NAFTA permit anyone of the parties to file complain is or review the practices of any other, it remains to be seen how they will be used. It is also worth noting that foreign Involvement in domestic politics can work both ways: the Salinas government actively opposed the November 1994 ballot initiative in California, Proposition 187, which would deny educational and non-emergency medical services to undocumented immigrants. Mexican government officials contacted Hispanic-American groups working against the proposition, prepared an advertising campaign reminding Californians of Mexicans' contributions to the stat, and declared that they would hire ;lawyers to help fight the initiative in the US courts should it pass (Golden 1994b).
} 
restricting their ability to adopt a more critical position. ${ }^{14}$ Labor actions have been especially important in the NAFTA context because so much of the debate surrounding NAFTA has centered on the labor question-whether US workers would be forced to compete for jobs with Mexican workers on the basis of lower wages, lax enforcement of labor legislation, and greater restrictions on union autonomy and militancy.

Whereas past efforts by US labor organizations to engage in international solidarity have produced mixed results at best, it is important to ask in what ways the current context generated by NAFTA alters the prospects for political action and facilitates new strategies in this transnational arena. ${ }^{15}$ The globalization of the economy and the formation of regional trading blocs provide an incentive for the resurgence of labor internationalism, even though numerous obstacles persist, and domestic political factors and institutions continue to weigh heavily on the actions and strategic decisions of labor movements. ${ }^{16}$ Nonetheless, regional economic integration may make cross-border actions more politically feasible and palatable to union memberships than in the past. Meanwhile, the formation of regional economic blocs in Europe, South America, and North America has reopened the debate on whether and how to engage $\mathrm{m}$ cross-national collaboration on labor strategies. ${ }^{17}$

A number of cross-national activities in the labor arena have emerged in recent years. These vary in terms of their objectives and the nature of their collaboration with counterparts. Some of them are reviewed here.

\section{TRANSNATIONAL COLLECTIVE BARGAINING}

This strategy involves cross-border cooperation in bargaining with a common multinational employer. While there are numerous cases of cross-border solidarity between unions, more concerted strategizing is rare. Nonetheless, one case that has received recent attention is that of the Farm Labor Organizing Committee (FLOG), an AFI-CIO affiliate, and the Sinaloa-based National Farm Workers' Union (Sindicato Nacional de Trabajadores Agricolas, SNTOAC), a CTM affiliate (Nauman 1993: 14; Moody and McGinn 1992; Browne et al. 1994:48; La Botz 1994: 9-10). ${ }^{18}$ Both have agreed to work together to improve conditions in each union by assisting each other in collective negotiations with their employer, Campbell's Soup Company. According to union leaders, this strategy has proven effective in increasing wages and benefits

\footnotetext{
${ }^{14}$ See Cook (1995) for a more detailed discussion of political constraints on Mexican unions under the Salinas administration.

${ }^{15}$ For critical accounts of past cases of labor internationalism, see Buchanan (1990) and Wedin (1991). On the Mexican experience, see Middlebrook (1992). Carr (1993, 1995), and Browne and Sims (1993).

${ }^{16}$ Denis McShane, of the International Metalworkers' Federation, has argued that international labor activity has changed, becoming increasingly horizontal rather than vertical: 'The traditional pyramid organization of unions with international contacts carefully controlled and monitored at the very peak runs counter to the most useful forms of international contacts which are horizontal between workers employed by the same company (or industry) in different countries. Fax, E-mail, and cheap travel also will encourage horizontal network building which contrasts with traditional trade union activity. Thus the new development of international trade unionism will pose a challenge to existing trade unions structures and international communications linkages', in 'Eight These on Trade Union Internationalism', presentation to Research Workshop on 'Democratic Institutions and Development in the Transition to a New International Order: The Role of Trade Unions', Graduate School of International Relations and Pacific Studies, University of California, San Diego, June 1991.

${ }^{17}$ For a discussion oi cross-national labor collaboration in Europe, see Turner (forthcoming); on labor actions in Mercosur, see de Freitas Barbosa and Candia Veiga (1994), and Portella de Castro (1995).

${ }^{18}$ For a history of the Farm Labor Organizing Committee, see Berger and Reza (1994).
} 
for members in both countries, although Mexican wages remain far lower than those of their US counterparts. ${ }^{19}$

The FLOC took the initiative to locate its Mexican counterpart in 1987, well before NAFTA had even been contemplated, in response to Campbell's threat to buy its tomato paste from Mexico if US workers made it 'too expensive' to do so in the USA. The US union then developed a strategy that consisted of improving conditions for Mexican workers so that the company could not use the disparity in costs against US workers. Through AFL-CIO contacts, the FLOC approached CTM patriarch Fidel Velazquez to secure his assistance in contacting the SNTOAC, and obtained support from both the CTM and AFL-ClO to set up a commission for ongoing talks between the two unions. This national-level support appears to have been important in making this transnational cooperation successful. Baldemar Velasquez, president of the FLOC, explains his union's strategy: 'Let's look at it that we are becoming less citizens of the nations in which we are born, and look upon ourselves as citizens of the companies that we work for. So what we're dealing with is the development of that international worker community' (La Botz 1994: 10).

\section{TRANSNATIONAL ORGANIZING}

Some initial cases of US-Mexican cooperation in union organizing have also taken place, most notably in the maquila industry along the border. The maquila sector has the lowest union density of any other manufacturing activity in Mexico. Where unions do operate in the maquila, these tend to be dominated by the official confederations (Confederacion de los Trabajadores Mexicanos (CTM), Confederation Revolucionaria de Obreros y Campesinos (CROC), and Confederation Regional Obrera Mexicana (CROM)). Due to the relatively high percentage of non-unionized plants, this sector is perhaps the most open to organizing. However, many obstacles remain: employers discourage unions, the workers themselves may even shun them, and the official unions can be extremely powerful and effective at stamping out any efforts to organize workers into more independent or democratic unions. ${ }^{20}$ Nonetheless, one independent labor federation in Mexico has begun to try to make inroads into the maquiladora sector. This is a relatively small labor federation, the Authentic Labor Front (Frente Autentico del Trabajo, FAT), that has been extremely active in the transnational arena. In Mexico, it is one of the founding members of foe Mexican Action Network on Free Trade (Red Mexicana de Accion Frente al Libre Comercio, RMALC), a network of approximately 100 citizens' and labor groups formed to critically evaluate for NAFTA, process and to propose alternatives to NAFTA. In 1992, the FAT and the United Electrical, Radio, and Machine Workers of America (UF) entered into what they called a 'strategic organizing alliance'. They decided to cooperate in organizing maquila workers, targeting those runaway plants that had employed UL-represented shops in the USA (Witt 1992; Browne and Sims 1993: 5). Although the unions involved are relatively small and the results are so far mixed, the alliance has received a great deal of publicity and has inspired other forms of direct assistance to Mexican unions.

Some indication that transnational organizing is occurring in the agricultural sector has also appeared recently. As part of their cooperative strategy, both the FLOG and the SNTOAC (mentioned above) were working to organize non-union

\footnotetext{
${ }^{19}$ Here the unions have been pushing for wage 'parity' by comparing the relationship between wages and cost-of-living in each country.

${ }^{20}$ On unionization in the maquiladora sector, see Carrillo (1991); Williams and Passe-Smith (1992); and Hualde (1994).
} 
farm labor in Texas and in south-central Mexico. The International Brotherhood of Teamsters was also contacting employees of US-based agricultural industries in Mexico's south-central farm belt (Moody and McGinn 1992). Teamsters Local 912 from California was especially active in collaborating with Mexican employees of Green Giant, which transferred its vegetable earning and packing operations from Watsonville to Mexico.

US unions have also launched 'adopt an organizer' campaigns to support union organizers that have been fired for their organizing work. The program, begun by the San Diego-based Support Committee for Maquiladora Workers, funds Mexican workers who devote themselves full-time to organizing in the border plants. US unions involved in the campaign so far include the UE, Teamsters, and UAW locals. Thus far the program has been targeted at a Zenith electronics assembly plant in Reynosa and at the Ford plant in Cuautitlan, among others (NAWWN 1993:10; Kalmijn 1994).

\section{TRANSNATIONAL SOLIDARITY}

This strategy encompasses different kinds of activities, from participation in tri-national meetings to solidarity actions in response to specific conflicts, to speaking tours and site visits. In recent years, labor organizations throughout the continent have engaged in activities of this type. For most these contacts are a starting point, leading to closer cooperation with counterparts and to the adoption of one oi the transnational strategies outlined above. For others, visits and meetings do not lead to more frequent communication. In any case, the number of contacts that has occurred is significant, especially when one considers the sparse communication among Canadian, US, and Mexican unions prior to 1990, especially at the grassroots level.

For many, a series of tri-national exchanges that brought together leaders and representatives from a broad range of unions and non-labor organizations provided the initial contact with counterparts across the border. In these trinational meetings, participants discussed tree trade, what positions groups should adopt, and whether and how they should cooperate in defending their interests (see Eisenstadt 1993). ${ }^{21}$ Participants stressed that the NAFTA did not only represent a threat to jobs, wages, and working conditions, but that it was also an opportunity to develop tri-national connections in order to help shape the continuing process of integration (Tri-national Exchange 1991: 3). In the first meeting, the Mexican side included top representatives from some of the principal labor organization in Mexico, including the telephone workers, the electrical workers, the airline pilots' association, and the teachers' union, as well as representatives of the FAT and of the CTM. This meeting marked one of the first in which both official and independent union representatives appeared together. From the labor movement on the US side were representatives from the Communications Workers of America (CWA), United Auto Workers (UAW), Amalgamated Clothing and Textile Workers' Union (ACTWU), International Ladies Garment Workers' Union (ILGWU), the AFL-CIO, the Coalition for Justice in the Maquiladoras, the International Union of Electrical Workers (IUF), and the Farm Labor Organizing Committee.

Several intra-industry meetings have also been set up in the auto sector, including one by the Chrysler-Ramos

\footnotetext{
${ }^{21}$ An outgrowth of these tri-national meetings was a NAFTA congress held in Mexico in 1991 at the same time as official negotiations on the agreement were taking place, sponsored by the Mexican Action Network on Free Trade, during which a social charter was developed (RMALC 1992).
} 
Arizpe union and the CTM, to which US and Canadian unions were invited (Middlebrook 1992), and another sponsored by the Transnationals Information Exchange (TIE), held in Mexico in 1991. At the TIE meeting, auto workers from the Big Three (Chrysler, Ford, and General Motors) discussed developing action plans by company and formed a tri-national committee to coordinate industry-wide cooperation and networking (Moody and McGinn 1992). The Mexican Telephone Workers' Union (Sindicato de Telefonistas de la Republica Mexicana, STRM) also signed an agreement with the US Communications Workers of America and the Communications and Electrical Workers of Canada pledging to defend worker rights in the face of regional integration and to exchange information on changes in their industry. ${ }^{22}$ Canadian, US, and Mexican electrical workers' unions met in Mexico in February 1994 to discuss common concerns. This meeting was especially significant given that the International Brotherhood of Electrical Workers (IBEW) and the Sindicato Mexicano de Electricistas (SME) carry more clout in their respective countries than either the UE or the FAT. ${ }^{23}$

Labor conflicts at US auto plants in Mexico have drawn the attention of the UAW and the AFL-CIO and have led them to lodge complaints about the handling of such conflicts. Among the most important of these cases has been the ongoing cries of conflicts at the Ford plant in Cuautitlan, outside of Mexico City. In 1990, the struggle over union representation left one worker dead at the hands of hired thugs who ambushed workers at the plant. ${ }^{24}$ The case revealed the collusion of the Mexican government, Ford Motor Company and the CTM in the repression of labor dissent and of union democracy in Mexican plants. ${ }^{25}$ The publicity this case received and the degree of solidarity shown by US unions was unprecedented. The Canadian Auto Workers and some UAW locals lent their support by publicizing the events in their own countries, pressuring government officials to complain about the matter, and by organizing a tri-national day of protest in which workers wore black ribbons on the anniversary of the Mexican auto worker's death. The UAW locals in St Paul and in Kansas City, Missouri, were especially active in organizing support for Cuautitlan workers; they formed a Mexico-US-Canada Solidarity Task Force and sent members to Mexico to witness union elections in 1991. The national UAW, meanwhile, was initially reluctant to engage in a nationwide campaign (Browne and Sims 1993: 6). These UAW locals and other US groups continue to follow events at Ford-Cuautitlan; with the help of the North American Worker-toWorker Network and electronic networks, supporters have begun to adopt the kinds of international action campaigns (telegrams to Mexican labor authorities and political leaders) that Amnesty International has long engaged in to draw attention to human, rights violations around the world (NAWWN 1993: 26). ${ }^{26}$

In the Cuautitlan case, solidarity focused primarily on supporting Mexican auto workers in their tight for union democracy rather than on trying to engage in collaborative collective bargaining or promote other kinds of demands, such

\footnotetext{
${ }^{22}$ A copy of the agreement is reprinted in Latin American Labor News, 5 (1992), 7.

23 'SourceMex- Economic News and Analysis on Mexico', Latin America Data Base, Latin American Institute, University of New Mexico, 5/7 (16 Feb. 1994).

${ }^{24}$ For an account of this case, see La Botz (1992) and Americas Watch (1990: 67-70).

${ }^{25}$ See La otra cara de Mexico, 21 (May-June 1991), 4-5

${ }^{26}$ In a post-NAFTA-vote strategy session, the North American Worker to Worker Network, a coalition of local unions and labor related NGOs, decided Lo support independent union organizing in Mexico through a variety of tactics, including an Emergency Response Network of people who would send faxes, telegrams, and takeout newspaper in the event of illegal firings or harassment of Mexican independent labor organizers.
} 
as wage increases (Middle-brook 1992). Such demonstrations of solidarity nonetheless annoyed the Mexican government and the CTM, both of which threatened the workers and pressured them to abandon their external alliances. ${ }^{27}$ In subsequent bargaining with Ford, however, the Cuautitlan union was able to draw on the added leverage gained through these alliances. It agreed not to enlist the help of US allies if Ford would meet some of its demands during collective bargaining. Authorities have discouraged auto workers at the Ford plants in Chihuahua and Hermosillo from adopting similar forms of cooperation with US allies (Middlebrook 1992).

In another case from the auto industry, workers from the Volkswagen plant in Puebla, Mexico, enjoyed the support of their German counterparts during a long strike in 1987. The German workers refused to step up production to compensate for the loss due to the strike in Mexico (Garza and Mendez 1987b). This solidarity helped the union to escape the fate that befell other auto unions in that year.

Managers at the Ford-Cuautitlan auto plant, for example, fired the workers during a strike, closed down the plant, and later reopened, rehiring some of the workforce at lower benefit and wage levels and with new work rules (Garza and Mendez 1987a; Middlebrook 1989: 86, 92). However, workers at Volkswagen were finally defeated during their 1992 strike when confronted with these same tactics (Nauman 1992; Othon Quiroz and Mendez 1992).

During a strike in 1990 at the Modelo Brewery, Teamsters in Chicago supported the strike by refusing to deliver shipments of the imported beer. A boycott of the product saw limited success in the United States, but was somewhat more successful in Canada and Europe. The Modelo workers belonged to a CTM-affiliated union, and their enlistment of foreign support drew the wrath of Fidel Velazquez, who also did everything in his power to defeat the strike (La Botz 1992). Other solidarity actions included a corporate campaign by Teamsters Local 912 against Green Giant products in cooperation with striking Mexican employees of the company (Moody and McGinn 1992:48).

The number of site visits and other kinds of exchanges and collaboration that have occurred ill recent years are too numerous to mention here, but some examples include the establishment of US and Mexican 'sister schools', arranged between US teachers and Mexican teachers belonging to the National Coordinating Committee of Education Workers, a large dissident current within the National Teachers' Union (Witt 1992). Announcements for tours to Mexico for US labor groups and others cover the pages of publications such as the Free Track Mailing and the Detroit based Labor Notes sponsored a Cross-Border Organizing Conference on the Mexican border in May 1994.

The maquiladora sector has received particularly strong attention since NAFTA was approved by the US Congress in November 1993. One maquiladora in Tijuana, Plasticos Bajacal (a division of Boston- based Carlisle Plastics), first received publicity prior to the NAFTA vote when a bus of US union activists and observers tried to visit the plant and were turned away by the management. In December 1994 human rights and union observers witnessed union elections at the maquiladora plant. The company had signed a contract with a union affiliated with the Regional Confederation of Mexican Workers (CROM); workers only learned of the existence of this union once they sought to organize themselves under the

\footnotetext{
${ }^{27}$ La Botz (1992); 'Weekly Commentary', ARKA Mexico Report. 21 Aug. 1992.
} 
auspices of another labor organization, the Revolutionary Labor Confederation (COR). During the representation election, workers were forced to vote out in the open and in the presence of managers, and made to sign their names beside their vote, US observers expressed shock and frustration at what they witnessed. Elections were finally halted because it was feared that plant managers would retaliate against the dissident workers. US observers felt that by publicizing the case, they were at least able to prevent retaliation against the COR supporters (Bacon 1993; Kalmijn 1994).

Two other cases that received much publicity in the USA during the winter of 1993-4 were the firings of workers who had been trying to organize a union in a General Electric maquiladora plant in Ciudad Juarez and at Honeywell in Chihuahua. In both cases, the organisation trying to organize the workers was the independent FAT. Its allies in the USA, the UE and the Teamsters reacted quickly to the firings. UE leaders wrote to the US Congress and pressed General Electric to reverse its position. Teamsters began carrying out leafleting campaigns at US General Electric plants. In January 1994, the unions finally succeeded in, getting General Electric to reinstate six of eleven workers who had been fired in Ciudad Juarez. Efforts continued to force the company to reinstate the remaining fired workers. Teamsters president Ron Carey wrote President Bill Clinton, warning him that unless the labor violations at the Honeywell and General Electric plants were resolved, they could become 'an international symbol of the violations of human rights now that MALT A has passed'. ${ }^{28}$

Perhaps most significant, on 15 February 1994, the UE and Teamsters became the first unions to file complaints to the new National Administrative Office (NAO) set up under the terms of the NAFTA labor side agreement (Rose 1994: A2). The US unions argued that by firing the union organizers, GE and Honeywell were violating the spirit of the trade agreement. In April the NAO responded by indicating that it would indeed review the complaints. This set an important precedent, especially given that the labor side accord had been criticized by labor advocates for its failure to include freedom of association and the right to organize, to strike, and to bargain collectively among those rights whose violation could subject a country to trade sanctions or to the withdrawal of NAFTA privileges. ${ }^{29}$ (Such penalties can be applied only in the case of persistent violations of domestic labor legislation in the areas of child labor, minimum wage, and occupational health and safety.) Nonetheless, after conducting a preliminary hearing the NAO stated that it would not pursue the complaints filed by the US unions. During the hearing the Secretary of the NAO steered the spotlight away from the conduct of US corporations in Mexico to the issue of Mexican government enforcement of labor legislation and found that the NAO could not conclude that Mexico had failed to enforce its labor laws (US National Administrative Office 1995). While US corporations had condemned the NAO's decision to hear the cases in the first place, they applauded the focus adopted during the hearing. Labor unions, of course, were disappointed. Teamsters' president Ron Carey said, 'The process set up by the NAFTA labor side agreement shows that fair trade was a false promise' (Bureau of National Labor Affairs 1994; Inside NAFTA 1994)..$^{30}$

\footnotetext{
28 'SourceMex-Economic News and Analysis on Mexico', Latin America Data Base, Latin American Institute, University, of New Mexico, 5/7 (6 Feb. 1994).

${ }^{29}$ For a discussion of the review mechanisms set up under the NAFTA labor side accord see Compa (1995).

${ }^{30}$ Subsequent filings, however, moved beyond these first cases. It: August 1994, a group of Mexican and US organizations filed a
} 


\section{POLITICAL BARGAINING IN THE TRANSNATIONAL ARENA}

Another strategy that some labor groups have adopted involves political bargaining in the transnational arena. This strategy was directly linked to the NAFTA debate, and involved both direct and indirect lobbying of US congressional representatives by Mexican groups. Indirect lobbying occurred through the exchange of information and networking with US-based organizations, which then lobbied members of Congress. Direct efforts included congressional testimony by individuals and representatives of Mexican groups who reported on conditions for workers in Mexico. The strategy was largely aimed at defeating NAFTA in the US Congress and with the US public, although it also helped to secure support tor side agreements and consideration of compensation mechanisms for likely users of free trade.

At the same time, because of the Mexican government's sensitivity to outside criticism, Mexican coalitions such as the Mexican Action Network were able to gain access to their own govern merit because of the attention they received and the role they played in the US debate on NAFTA. Under circumstances in which the Network would not otherwise have played much of a political role within the country, its use of transnational spaces gave it greater leverage within national boundaries. To the extent that the Network has played a role in providing information about Mexican labor and environmental conditions to unions and other groups in the United States and to the US Congress, it has also acted indirectly to reform domestic politics in Mexico. This is so because the Mexican government acted to pre-empt criticism of Mexican practices and to address the concerns of those in the Congress who would decide NAFTA's fate.

\section{Popular Sector Strategies in a Transnational Political Arena: Future Prospects}

Several questions emerge in considering how the future evolution of a transnational political arena is likely to affect popular sector strategies in the NAFTA era. Here again it is important to distinguish between two phases; (1) the period prior to the vote in the US Congress on 17 November 1993; and (2) the period after the vote, and especially after 1 January 1994, when the NAFTA formally took effect (the NAFTA era).

\section{WILL CROSS-BORDER COALITIONS SURVIVE INTO THE NAFTA ERA?}

A first question that emerges is whether the groups that formed during the NAFTA debate process will survive into the post-NAFTA vote era. The NAFTA, debate dearly signaled the coming together of diverse single-issue groups and networks to influence the NAFTA process. The coalitions that were forged were therefore often loose and contained at times conflicting and competing interests (Tri-national Exchange 1991). The split that occurred between US labor and environmental groups and within the environmental camp when the side agreements were announced was one example of the kinds of schisms that existed. It is reasonable to believe, therefore, that after the NAFTA vote these loose coalitions would drift apart, each organization tending again to its particular area of interest and to issues long neglected by the anti-

complaint against a Sony plant in Nuevo Laredo (Davis 1994). This case, which also concerned the issues of association and the right to organise, moved through the NAO review process to the point of ministerial consultations, the highest level to which complaints over these issues can proceed (US National Administrative Office 1995). In Feb. 1995, the Mexican telephone workers union also filed a complaint with the Mexican NAO regarding Sprint's firing of workers during a union organizing drive in San Francisco (Pattee 1995). 
NAFTA campaign.

A smaller number of groups may succeed in shifting the focus and their strategies toward monitoring the effects of NAFTA and even toward trying to extend ties to similar networks in the rest of Latin America. ${ }^{31} \mathrm{~A}$ few new groups may emerge as well in the USA and Canada to monitor and support causes in Mexico, perhaps bail ding on earlier contacts. Other organizations may find also that contacts initiated during the debate phase will lead to collaboration in the redefinition of more long-term strategies.

Human rights and environmental issues may continue to receive strong attention by international allies in conjunction with Mexican NGOs. The prior existence of these particular issue-area networks and the existence of multiple Mexican organizations dealing with these issues point to the likelihood of continued collaboration. Labor rights and democracy questions may still be more difficult, however. In the case of the former, strong control over and protection of this arena on the part of both the Mexican government and official trade unions in Mexico may complicate efforts to shed light on labor rights violations. During negotiations between the three governments on the labor side accord, Mexican government officials made it very clear that they considered the labor question to be a national sovereignty issue; the resulting agreement was noticeably weak on labor protections. This, combined with the resistance of US companies in Mexico, may make it more difficult for US and Mexican allies to advance in this arena, even though the few steps that have been taken so far are significant. More open intervention in support of democracy in Mexico has also been complicated, as evidenced by the considerable debate surrounding the issue of whether or not to permit foreign election observers in $1994 .^{32}$

\section{WILL THE RESPONSE TO CHIAPAS BE REPRESENTATIVE OF POLITICS IN THE NAFTA ERA?}

The Chiapas uprising represented the first NAFFA-era political crisis. For this reason, it is important to note how domestic and international groups mobilized in response to it. Domestic and international human rights, environ mental, labor, and indigenous groups reacted quickly to the government and military actions in Chiapas. Mexican intellectuals and analysts carried on an important debate in the national press and forged a consensus around peaceful negotiations. The anti-NAFTA coalition in the US Congress was also mobilized, as were congressional representatives who had voted for NAFTA but who were alarmed that Chiapas might signal the advent of widespread political instability in Mexico, contrary to what many NAFTA supporters had predicted. Several congressional representatives traveled to Chiapas on fact-finding tours, and once again hearings on Mexican political affairs were held in Washington, DC. Meanwhile, Mexican political parties reached an agreement on a series of electoral reforms, raising the possibility of Fair presidential elections in August 1994 for the first time. While it is certainly true that the catalyst for political reform was the events in Chiapas, and not NAFTA itself, the NAFTA era has introduced new interests and new forces that may have permanently altered the

\footnotetext{
${ }^{31}$ Indeed, one of the leaders of the Mexican Action Network mentioned these as the new tasks the anti-NAFTA coalitions would try to adopt (personal communication, Mexico City, 13 Jan. 1994).

${ }^{32}$ A category called 'invited foreign visitors' was finally devised in 1994 . Approximately 1,000 foreigners came to observe the 1994 elections, the great majority of them from the United States.
} 
environment in which Mexican politics unfolds. ${ }^{33}$

Throughout 1994-5 the Mexican government also found itself caught in the midst of a political and economic transition, and therefore more vulnerable not only to US criticism (whose influence may indeed be less after the NAFTA vote), but principally to domestic pressures, in an interesting reversal of the pre-NAFTA-vote period. ${ }^{34}$ The political context of the presidential succession and the Chiapas rebellion made the government especially vulnerable and gave citizens groups increased bargaining leverage. Thus, while the new political environment of the NAFTA era did not necessarily create the government's crisis, it certainly may have added to the regime's vulnerability and to domestic groups' leverage.

A second question, then, is whether the intense spotlight on Mexican domestic politics and the activation of international networks that was witnessed in the immediate wake of the Chiapas uprising will remain permanent features of NAFTA- era politics. The Chiapas rebellion, political assassinations, and the presidential elections focused high levels of attention on Mexico during NAFTA's first year. Whether this heightened level of attention and intensity of interaction will persist after the presidential elections is difficult to answer at this time. ${ }^{35}$ In any case, what the pre- NAFTA-vote period facilitated was the creation of transnational networks and the generation of a transnational political arena. The Chiapas uprising, coming as soon as it did after the NAFTA vote, may have helped to consolidate these networks and to underscore their importance. Whether or not these same levels of attention are witnessed on a permanent basis, the contacts, alliances, and networks could well be in place to spring into action again should another crisis event call for it.

\section{WHAT DIFFERENCE WILL INSTITUTIONALIZATION, OR THE LACK OF IT,}

\section{MAKE?}

A third question is how the presence or lack of institutionalization is likely to affect popular sector politics in a transnational arena. As mentioned earlier, NAFTA involves a relatively limited degree of institutional innovation. Among the institutions to be created under the trade agreement are the NAFTA trade commission, two secretariats (one for labor and one for the environment), National Administrative Offices (NAOs) in each country, a border commission, and the North American Development Bank. The key question for this discussion is how the environmental and labor secretariats and the NAOs will operate, and whether they will serve to complicate or to complement the efforts by grassroots organizations. As discussed above for the case of labor, the results thus far have been mixed, although it is perhaps still too early to tell what the full impact of the labor side accord will be. At the same time it is important to recognize that the

\footnotetext{
${ }^{33}$ For further elaboration of this argument, see Heredia (1994). For additional discussion on the relationship between NAFTA and democratization in Mexico, see P. Smith (1992) and R. Pastor (1992).

${ }^{34}$ See the remarks of Mexican Deputy Foreign Secretary Andres Rozental, in response to the congressional hearing convened by US Representative Robert Torricelli to determine whether the Mexican army had committed human rights abuses in Chiapas: 'The implementation of the North American Free Trade Agreement does not give anyone outside Mexico the right to sit in judgment on matters that Mexicans are solely responsible for resolving' ('Mexico Tells U S. to Stop Meddling', San Francisco Chronical, 4 Feb. 1994, p 14A).

${ }^{35}$ This chapter was written prior to the 1994 peso devaluation: an analysis of transnational interaction during the ensuing economic crisis is therefore beyond its scope.
} 
procedures for tiling complaints with the NAO, which require that allegations of rights violations in one country be presented before the NAO of another country, encourage cross-border collaboration. Since the labor side accord removes some of the most controversial issues (such as the right to organize, to strike, and to collective bargaining) from the scope of sanctionable violations, it maybe that these kinds of rights issues must still be handled primarily through other forms of political pressure and popular-sector organizing, with the use of the institutional channels established under NAFTA serving as a complementary strategy. The use of both strategies, then, may well foster further transnational popular sector cooperation.

The relative lack of institutionalization could affect popular sector groups involved in transnational political strategies in another way. So much of what has occurred in the way of cross-border contacts has been based on the undertakings of committed activists and local union leaders, who are subject to burnout and removal, and on organizations with relatively limited resources. An important question here is the extent to which external funding for Mexico support work (for organizations in the USA and Canada) and international financing of popular organizations and NGOs in Mexico will become available. In the 1980s, a number of private foundations supported US organizations in their solidarity work with Central American groups. Will Mexico-related support work be the new focus of foundation aid in the 1990s?

\section{Conclusion}

In spite of the perceived (and real) limitations that the implementation of free trade agreements implies for popular sector groups, this chapter has argued that such regional free trade agreements may also expand the strategic options and political opportunities available to these groups through the simultaneous generation of a transnational political arena. All movements toward regional free trade appear to involve some degree of compromise of national sovereignty, as well as provide some incentive for cross border collaboration among non-state actors. It may well be, however, that the particular characteristics of North American regional integration and of the circumstances in which the debate over NAFTA took place have generated an especially unique transnational political space in the region. The tremendous political, economic, and cultural asymmetry between the United States and Mexico helped to drive US, Canadian, and Mexican non-state actors across national boundaries in their search for allies to combat an agreement that they viewed as harmful to their interests. The alliances and networks built during this period prior to the NAFTA vote may help to make transnational politics a permanent feature of the NAFTA era, although the visibility and intensity of transnational political interaction may now assume lower levels most of the time.

The advantage of interacting in the transnational political arena for popular sector groups that are strongly constrained by national politics in what they can achieve is that they may be able to obtain greater bargaining leverage in dealing with their own governments. Whether, in the Mexican case, the ability to do so is made more permanent as a result of NAFTA or whether time and institutionalization will overtake cross-border grassroots mobilization efforts remains to be seen. What appears clear at this point is that in the complex process of economic and political change that lies at the core of the globalization of the economy and the fashioning of region al trade agreements, there are opportunities to be found. Part of the necessary task, then, is to think of new ways to conceptualize these changes so that these 
opportunities can be seized more readily. 